\title{
Facial lesions caused by renal osteodystrophy in a patient with chronic renal insufficiency: A case report
}

\author{
Lesões faciais por osteodistrofia renal em paciente com \\ insuficiência renal crônica: Relato de caso
}

\begin{abstract}
Purpose: Chronic renal insufficiency (CRI) is the last stage of a chronic renal condition in which the kidney loses its filtration and endocrine functions. Chronic endocrine hypofunction causes generalized damage to the body known as Uremic Syndrome, which affects the central nervous system as well as the cardiovascular, hematologic, dermatologic, ophthalmic, endocrine, respiratory, gastrointestinal and skeletal systems. The present study reports the case of a female patient with CRI who presented facial osteodystrophy of the osteitis fibrosa type, and highlights the main features of this condition.

Case Description: A 24-year old, female, Caucasian patient presented chronic glomerulonephritis recurrence and lost the transplanted kidney five years before, undergoing arteriovenous fistula hemodialysis three times a week. She presented swelling of the left masseter area with a hard consistency on palpation, covered by intact skin, swelling at the bottom of the left atrium, with a hard consistency on palpation, a mucosa-like color and absence of inflammation signs, suggesting expansive bone lesions on the face. These features were compatible with hyperparathyroidism brown tumor and/or osteodystrophy. The CT scan showed expansive bone lesions of heterogeneous appearance on the left jaw, maxilla/nasal floor, and right frontotemporal suture areas. The clinical and histopathological characteristics of the lesion, in association with PHT hormone high serum levels led to renal osteodystrophy diagnosis. The patient was referred to the nephrology services.

Conclusion: Osteodystrophic bone alterations have a high prevalence in renal disease patients, and the dentist must take these alterations into consideration in bone lesion diagnosis for this specific group of patients.
\end{abstract}

Key words: Chronic renal insufficiency; renal dialysis; renal osteodystrophy

\section{Resumo}

Objetivo: A Insuficiência Renal Crônica (IRC) é o último estágio da doença renal crônica, na qual o rim perde sua função de filtração e endócrina. A hipofunção endócrina renal ocasiona danos generalizados ao organismo, que no conjunto são conhecidos como Síndrome Urêmica, sendo composta por danos que comprometem o sistema nervoso central, assim como os sistemas cardiovasculares, hematológicos, dermatológicos, oftálmicos, endócrinos, respiratórios, gastrointestinais e ósseos. O presente estudo irá relatar o caso de uma paciente portadora de IRC apresentando osteodistrofia em face do tipo osteíte fibrosa, evidenciando as principais características dessa doença.

Descrição do caso: Uma paciente de 24 anos, sexo feminino, caucasiana, apresentou glomerulonefrite recorrente após perda do rim transplantado, estando sob hemodiálise três vezes por semana. Apresentou inchaço da área do m. masseter esquerdo com consistência dura à palpação, coberto por pelo de aspecto normal, inchaço do átrio esquerdo, com consistência dura e ausência de sinais inflamatórios, sugerindo lesões ósseas na face. Estas características eram compatíveis com tumor marrom de hiperparatireoidismo e/ou osteodistrofia. A imagem de tomografia computadorizada mostrou lesões ósseas expansivas de aparência heterogênea na mandíbula esquerda, assoalho da maxila e nasal, e nas áreas de sutura frontotemporal direita. As características clínicas e histopatológicas da lesão, em associação com níveis séricos elevados de hormônio PHT conduziram ao diagnóstico de osteodistrofia renal. A paciente foi encaminhada para o serviço de nefrologia.

Conclusão: As alterações ósseas osteodistróficas são de grande prevalência em pessoas com doença renal, tendo o cirurgião-dentista o dever de levá-las em consideração no diagnóstico de lesões ósseas neste grupo específico de pessoas.

Palavras-chave: Insuficiência renal crônica; diálise renal; osteodistrofia renal

\author{
Rafael Machado Karsburg a \\ Kátia Regina de Campos b \\ Maria Paula de Siqueira Melo Peres ' \\ Sheyla Batista Bologna d \\ Silvia Vanessa Lourenço ${ }^{e}$ \\ Juliana Bertoldi Franco $f$
}

\begin{abstract}
- Residência em Odontologia Hospitalar, Hospital das Clínicas da Faculdade de Medicina da Universidade de São Paulo (HCFMUSP), São Paulo, SP, Brasil

${ }^{b}$ Curso de aprimoramento em Odontologia Hospitalar, HCFMUSP, São Paulo, SP, Brasil

c Divisão de Odontologia do Instituto Central do HCFMUSP, São Paulo, SP, Brasil

¿Curso de Doutorado em Ciências da Saúde, Disciplina de Dermatologia, HCFMUSP, São Paulo, SP, Brasil

e Disciplina de Patologia Geral, Faculdade de Odontologia, Universidade de São Paulo, São Paulo, SP, Brasil

f Serviço de Odontologia do Hospital Auxiliar de Suzano do HCFMUSP, São Paulo, SP, Brasil
\end{abstract}

\section{Correspondence:}

Juliana Bertoldi Franco

Av. Dr. Eneas de Carvalho Aguiar, 155

(PAMB, 6 andar, sala 02)

Divisão de Odontologia do Instituto Central do HCFMUSP

São Paulo, SP - Brasil

05403-900

E-mail: juliana.franco@hc.fm.usp.br

Received: July 21, 2011

Accepted: April 10, 2012

Conflict of Interests: The authors state that there are no financial and personal conflicts of interest that could have inappropriately influenced their work.

Copyright: (c) 2011 Karsburg et al.; licensee EDIPUCRS. This is an Open Access article distributed under the terms of the Creative Commons AttributionNoncommercial-No Derivative Works 3.0 Unported License. 


\section{Introdução}

The kidneys regulate different systems in the human body, being responsible for body metabolite excretion, electrolyte balance and arterial blood pressure regulation, red blood cell secretion, gluco-neogenesis, and vitamin D production (1).

The final kidney disease stage is called Chronic Renal Insufficiency (CRI), which is characterized by extensive damage as well as a progressive and irreversible loss of the kidney glomerular, tubular and endocrine functions. A reduced or absent function of the kidneys can lead to alterations in the function of other body systems, known as Uremic Syndrome. Major uremic syndrome manifestations include central and peripheral neurological damage, as well as cardiovascular, skin, ophthalmic, endocrine, gastrointestinal and bone damage (2-4).

The kidneys play an important role in bone metabolism due to their participation in vitamin $\mathrm{D}$ synthesis. The $1,25-$ dihydroxyvitamin $\mathrm{D} 3$, or simply vitamin $\mathrm{D}$, in association with other hormones and minerals, is responsible for mediating the intestinal absorption of calcium, which influences plasma calcium levels and bone metabolism(1). When the endocrine function of the kidneys has been impaired, there occurs a decrease in vitamin $\mathrm{D}$ production, leading to a reduction in dietary calcium absorption, thus decreasing the availability of this mineral in the blood. This hypocalcemia will compensatorily increase the parathyroid hormone (PTH) serum levels, characterizing a secondary hyperparathyroidism condition to CRI. This hyperparathyroidism, if left untreated, can trigger characteristic bone lesions known as renal osteodystrophy (3).

Renal osteodystrophy is defined as a skeletal change showing specific characteristics whose etiology is related to hormonal deregulation in the uremic syndrome, which interferes with bone apposition and resorption in the patient with CRI, and can affect up to $50 \%$ of the patients with end-stage renal disease (ESRD) (5). Facial skeleton lesions are the first symptoms in most cases (6). Osteodystrophy can be divided into three groups: high remodeling bone disease, low remodeling bone disease, and an in-between group (Table 1) $(5,7)$.

The present study aims to report a case of a patient with CRI who developed the high remodeling facial osteodystrophy type (osteitis fibrosa) and to discuss the main features of the disease, as well as its associations with bone pathologies.

\section{Case Report}

A 24-year old, female, Caucasian patient with ESRD caused by glomerulonephritis, on a kidney transplant waiting list and undergoing dialysis was referred to the Dentistry Division of the Central Institute at the Clinics Hospital of the Medicine School of São Paulo University complaining about odontalgia in the left mandibular area.
Table 1. Renal osteodystrophy lesions and their characteristics (3)

\begin{tabular}{|c|c|c|}
\hline Group & Subtype & Characteristics \\
\hline 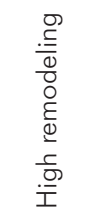 & Osteitis Fibrosa & $\begin{array}{l}\text { PHT increase due to hypocalcemia/ } \\
\text { hyperphosphatemia, intense } \\
\text { osteoblastic and clastic activity, } \\
\text { fibrous cord lesions and normal or } \\
\text { increased mineralization }\end{array}$ \\
\hline $\begin{array}{l}\frac{0}{\frac{1}{0}} \\
\frac{.0}{0} \\
\frac{0}{0} \\
\frac{5}{0} \\
\frac{0}{ \pm}\end{array}$ & Mixed disease & $\begin{array}{l}\text { An association of two } \\
\text { osteodystrophic entities }\end{array}$ \\
\hline $\begin{array}{l}\text { O) } \\
\frac{.}{0} \\
\frac{D}{0} \\
0 \\
\frac{E}{1}\end{array}$ & Osteomalacia & $\begin{array}{l}\text { Accumulation of non-mineralized } \\
\text { osteoid matrix due to hipocalcemia/ } \\
\text { hypo-phosphatemia, reduction } \\
\text { in vitamin D production or bone } \\
\text { toxicity by aluminum }\end{array}$ \\
\hline o & $\begin{array}{l}\text { Aplastic or adynamic } \\
\text { bone disease }\end{array}$ & $\begin{array}{l}\text { Reduction in osteoid secretion and } \\
\text { thickness of unknown etiology }\end{array}$ \\
\hline
\end{tabular}

At the interview, the patient reported having been submitted to kidney transplantation eleven years before; however, due to chronic glomerulonephritis recurrence, she lost the transplanted kidney five years before. So she needed to undergo arteriovenous fistula hemodialysis three times a week. The patient denied having any bad habits, drug allergies, diabetes, or other relevant systemic comorbidities, and mentioned the use of the following medications: calcium phosphate, sodium fluoride, nifedipine, sevelamer hydrochloride, omeprazole and erythropoietin.

Upon extra-oral examination, a swelling of the left masseter area showing a hard consistency on palpation, and covered with intact skin, was observed. Upon intra-oral examination, tooth 36 , showing extensive carious lesions and pulpal involvement, was identified as the source of the pain reported by the patient; in addition, a swelling at the bottom of the left atrium, with a hard consistency on palpation, a mucosa-like color and the absence of inflammation signs, suggestive of the presence of expansive bone lesions on the face and compatible with hyperparathyroidism brown tumor and/or osteodystrophy, was found. The patient also presented mild generalized periodontitis in tooth-supporting tissues.

A CT scan and blood tests (blood count and coagulation profile with platelet count) were asked so that surgical removal and local biopsy could be performed.

The CT scan identified expansive bone lesions of heterogeneous appearance on the left jaw (Fig. 1 and Fig. 2), maxilla/ nasal floor (Fig. 3 and fig. 4), and right frontotemporal suture (Fig. 5 and Fig. 6) areas.

The patient underwent lower left first molar extraction with antibiotics prophylaxis as prescribed by the American Heart Association ( $\mathrm{g}$ amoxicillin 1 hour before procedure), since she was being submitted to arteriovenous fistula dialysis. During surgery, bone fragments from the tooth socket were collected for pathology. The microscopic aspect excluded brown tumor occurrence, and described numerous bone trabeculae surrounded by connective tissue rich in fibroblasts. 

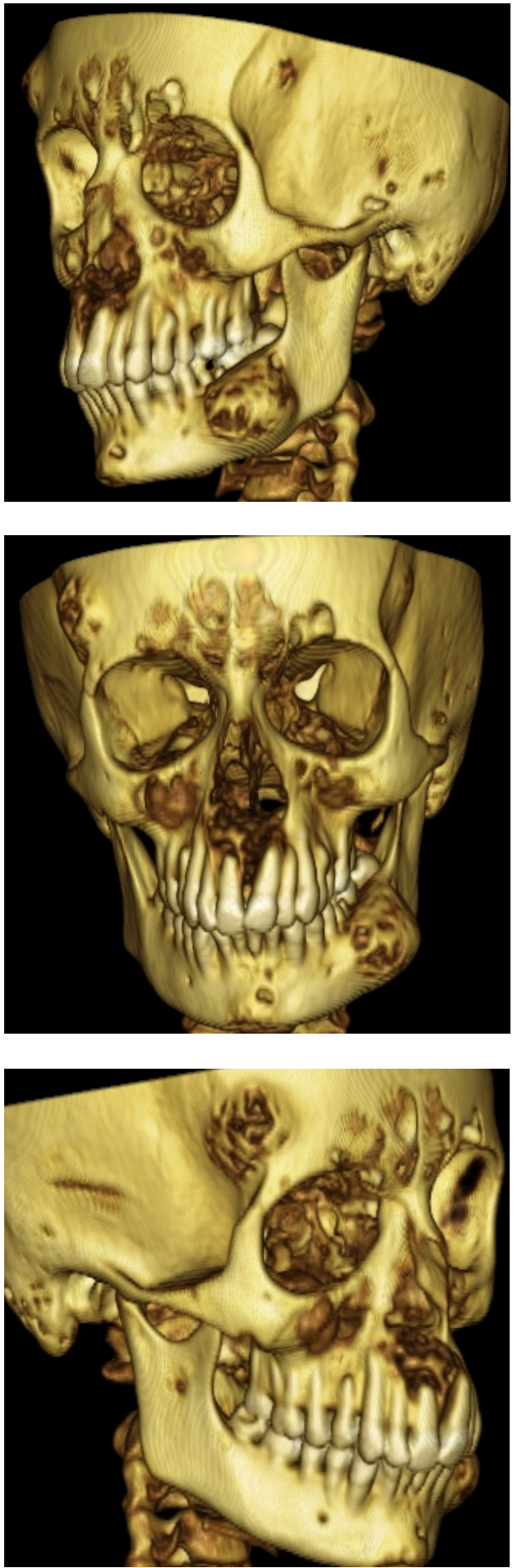

Fig. 1. Three-dimensional reconstruction in CT scan: an expansive area in the left mandible extending from the alveolar ridge to the base of the mandible in the molar region was observed.

Fig. 2. CT axial cut with bone window: expansive area of heterogeneous density in the left mandible.

Fig. 3. Three-dimensional reconstruction in CT scan: an expansive area in the anterior mandible, nasal floor, left side of the jaw and frontoparietal suture was observed.

Fig. 4. CT axial cut with bone window: expansive area of heterogeneous density in the anterior mandible.

Fig. 5. Three-dimensional reconstruction in $\mathrm{CT}$ scan: expansive area in the right frontoparietal suture.

Fig. 6. CT axial scan: areas of heterogeneous bone expansion in the right and left frontoparietal suture.
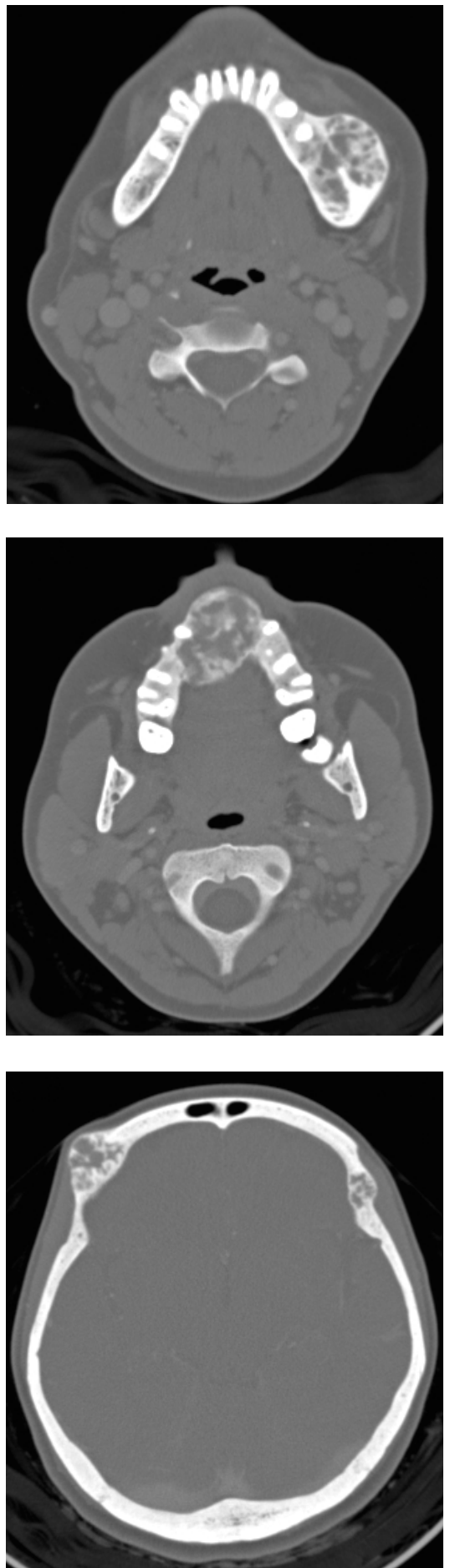

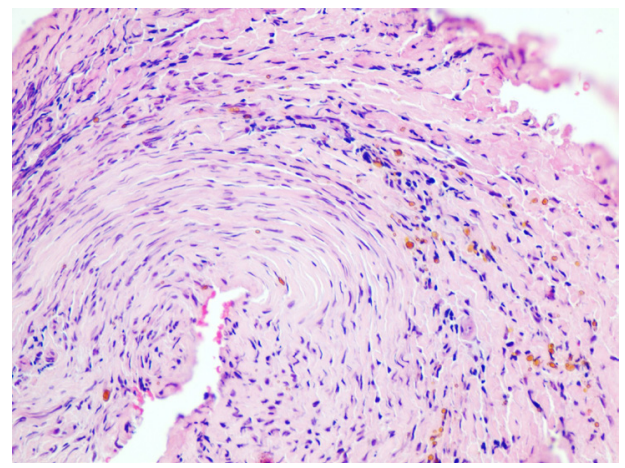

Fig. 7. Histological image of the lesion composed of dense connective tissue permeated by inflammatory cells and hemosiderin pigments. There is no presence of multinucleated giant cells. (optical microscopy, 40x zoom, HE). 
The clinical and histopathological characteristics of the lesion, in association with PHT hormone high serum levels $(1,554 \mathrm{pg} / \mathrm{mL}$ with a 16 to $18 \mathrm{pg} / \mathrm{mL}$ reference range) contributed to renal osteodystrophy diagnosis.

The patient was referred to the nephrology service, where she was already being monitored, for medical procedures. After the attempted regulation of secondary hyperparathyroidism to renal disease through medication, a surgical procedure for the removal of the hyperplastic parathyroid glands was performed, and healthy fragments were implanted in the right upper limb so as to preserve the glandular function.

The regression of the patient's facial lesions is currently being monitored and, in case it is not aesthetically favorable enough, repair bone surgery will be proposed to improve the patient's aesthetic facial condition.

\section{Discussion}

According to Proctor et al. (8) CRI can generate a wide range of oral-facial and dental manifestations, such as gingival hyperplasia, periodontal disease, xerostomia, lichen planus, uremic stomatitis, candidiasis, herpes simplex, delayed dental eruption, enamel hypoplasia, dental mobility and renal osteodystroph. In this study, the patient had CRI, having only developed periodontal disease and high bone remodeling osteodystrophy (osteitis fibrosa) type as oral manifestations.

Diagnosis of the specific osteodystrophy type is a rather complex process (9), and various biochemical markers and radiographic findings are used so as to facilitate this stage. However, a sensitive, specific non-invasive method that is able to identify the specific osteodystrophic disease is not yet available (5). Serum PTH and alkaline phosphatase levels are the most commonly used blood tests for this purpose (5), their usefulness is, however, questionable (10). In the clinical case reported, the blood test evaluation contributed to osteitis fibrosa diagnosis, when a high PTH serum level $(1.554 \mathrm{pg} / \mathrm{mL})$ was observed, suggesting secondary hyperparathyroidism.

Due to the low sensitivity of blood analyses, the most important exam in the identification of the severity and nature of bone disease is still biopsy $(5,10)$. The histopathological analysis identified dense connective tissue permeated by inflammatory cells and hemosiderin pigments, in agreement with the histopathological findings for osteitis fibrosa diagnosis as described by Hata et al. (11) (Fig. 7).

To reach a diagnosis of bone lesion caused by renal osteodystrophy, a differential diagnosis between fibrous dysplasia, Paget's disease (9) and brown tumor (12) must be made. The most important factors to distinguish a renal osteodystrophy lesion from other bone lesions are the report of chronic kidney disease, hemodialysis (9) and secondary hyperparathyroidism, once the brown tumor is more likely to occur in primary hyperparathyroidism (12) and shows a faster growth (13). In 2007, Damm et al. (4) stated that every expansive fibrous-osseous lesion in the maxillary bones of patients with CRI must be considered an osteodystrophic lesion until proven otherwise. In this study, the patient had had renal insufficiency for over ten years, and had been doing arteriovenous fistula hemodialysis three times a week both in the period that preceded the kidney transplantion and after the loss of the transplanted organ; the patient had also developed secondary hyperparathyroidism. These factors, along with the histological analysis, were important for establishing the renal osteodystrophy diagnosis.

The most common type of osteodystrophy is osteitis fibrosa, which affects about $30 \%$ of the patients with chronic renal disease $(2,10)$. Its most usual complications include osteopenia and bone fractures (6), affecting mainly long bones, ribs and the pelvis; it also affects the maxillary bones relatively frequently, which can be a sign of the onset of the disease (14). The most common maxillary radiographic findings include changes in trabecular bone pattern, a diffuse frosted glass appearance, and loss of lamina dura (9). As to the case discussed, there had been no history of bone fractures or long bone affection. However, dental examination revealed bone pattern alterations in the maxilla, mandible and frontal bone areas, in agreement with the findings of Kalivas et al. (9) who reported frosted glass bone characteristics and trabecular bone changes.

A brief review of osteitis fibrosa clinical cases in literature reveals the description of similar characteristics, such as the slow progression of bone lesions, high parathyroid hormone levels, a long hemodialysis history, histopathological findings, trabecular bone interspersed with fibrous connective tissue, the expansive and painless character of the lesions, and treatment based on secondary hyperparathyroidism control, mainly by means of parathyroidectomy $(9,14,15)$. The case reported in this study presented similar characteristics.

High modeling bone disease treatment is based on the control of hyperparathyroidism secondary to the renal disease, performed by drug administration or by parathyroid removal (7). In this case report, due to the development of important bone lesions and the low response to the drug therapy used in calcemia and hyperparathyroidism control, the patient was submitted to parathyroidectomy with parathyroid fragment implant in the right upper limb. After the mineral and hormone serum levels related to bone metabolism have been corrected, the patient is presently undergoing dental treatment to follow the regression of the lesions and, if this alone is aesthetically insufficient, she may be referred to bone repair surgery, similarly to a case reported by Neves et al. (7).

\section{Conclusions}

From the clinical case under discussion, it may be concluded that bone alterations related to chronic renal insufficiency have a high prevalence rate in this population; for diagnosis, the professional must take into account the possibility of lesions related to bone metabolism altered by CRI, such as the different osteodistrophy types, without, however, disregarding the possibility of other 
neoplastic and / or inflammatory pathologies these lesions can mimic.

It is important that the dentist should be informed of any systemic diseases of the patient; the professional should as well know how to identify the interference of the drugs and treatments to control them. Only then will the dentist be able to perform the correct diagnosis and propose the most adequate treatment for the patient.

References 1. Eaton DC, Pooler JP. Fisiologia Renal de Vander. 6 ${ }^{a}$ ed. Porto Alegre: Artmed; 2006.

2. Kerr AR. Update on renal disease for the dental practitioner. Oral Surg Oral Med Oral Pathol Oral Radiol Endod 2001;92:9-16.

3. Júnior JER. Insuficiência Renal Crônica. In: Cruz J, Praxedes JN, Cruz HMM, editors. Nefrologia. $2^{a}$ ed. São Paulo: Sarvier; 2006.

4. Damm DD, Neville BW, McKenna S, Jones AC, Freedman PD, Anderson WR, et al Macrognathia of renal osteodystrophy in dialysis patients. Oral Surg Oral Med Oral Pathol Oral Radiol Endod 1997;83:489-95.

5. Roe S, Cassidy MJ. Diagnosis and monitoring of renal osteodystrophy. Curr Opin Nephrol Hypertens 2000;9:675-81.

6. Hruska KA, Teitelbaum SL. Renal osteodystrophy. N Engl J Med 1995;333:166-74.

7. Neves CL, Neves KR, Jorgetti V. Osteodistrofia Renal. In: Cruz J, Praxedes JN, Cruz HMM, editors. Nefrologia. $2^{a}$ ed. São Paulo: Sarvier; 2006

8. Proctor R, Kumar N, Stein A, Moles D, Porter S. Oral and dental aspects of chronic renal failure. J Dent Res 2005;84:199-208.

9. Kalyvas D, Tosios KI, Leventis MD, Tsiklakis K, Angelopoulos AP. Localized jaw enlargement in renal osteodystrophy: report of a case and review of the literature. Oral Surg Oral Med Oral Pathol Oral Radiol Endod 2004;97:68-74.

10. Ferreira A, Drueke TB. Biological markers in the diagnosis of the different forms of renal osteodystrophy. Am J Med Sci 2000;320:85-9.

11. Hata T, Irei I, Tanaka K, Nagatsuka H, Hosoda M. Macrognathia secondary to dialysisrelated renal osteodystrophy treated successfully by parathyroidectomy. Int J Oral Maxillofac Surg 2006;35:378-82.

12. Benjelloun M, Tarrass F, Alaoui L, Medkouri G, Hachim K, Gharbi MB, et al. Marked facial enlargement in secondary hyperparathyroidism. Nephrol Dial Transplant 2007;22:3082-3.

13. Tarrass F, Benjelloun M, Bensaha T. Severe jaw enlargement associated with uremic hyperparathyroidism. Hemodial Int 2008;1:316-8.

14. Adachi PL, da Silva Santos PS, de Magalhaes MH, Martins MT. Renal osteodystrophy manifesting as localized enlargement of the jaw. Nephrol Dial Transplant 2007;22:2398-9.

15. Chang JI, Som PM, Lawson W. Unique imaging findings in the facial bones of renal osteodystrophy. AJNR Am J Neuroradiol 2007;28:608-9. 